\title{
Persistent Issues with the Development of Halal Tourism in North Sumatera
}

\author{
Hefriansyah $^{1}$, Asmuni $^{2}$, Muslim Marpaung ${ }^{3} \&$ Hendri Tanjung ${ }^{4}$
}

\begin{abstract}
The present study aims to uncover the problems, aspects, solutions and strategies of halal travel and tourism in North Sumatera, Indonesia. This study employs Analytic Network Process (ANP) methods in three steps, first, problem decomposition, pair-wise comparison questionnaire, and synthesis and analysis. ANP also used to gather the opinion and responses from the experts. From this study, it was found that the problems of improving halal travel and tourism based on their level of significance are as follows: Environment, Access and Services, and Communication. Meanwhile, the priority of aspects to improve halal travel and tourism based on their level of significance are environment, access, services, and communication. Similar to problems and aspects, solutions based on their level of significance are environment, access, services and communication. In addition, top three strategies that recommended from this study are ecosystem, destination, and accessibility and connectivity. The findings of this study are also furnished with some recommendation from the industry perspective and stakeholders of halal travel and tourism.
\end{abstract}

Keywords: Halal travel and tourism, Analytic Network Process, North Sumatra, Toba Lake

\begin{abstract}
Abstrak. Penelitian ini bertujuan untuk mengungkap permasalahan, aspek, solusi dan strategi pariwisata halal. Penelitian ini menggunakan metode Analytic Network Process (ANP) dalam tiga tahap, pertama, dekomposisi masalah, kuesioner perbandingan berpasangan, sintesis dan analisis. ANP juga digunakan untuk mengumpulkan pendapat dan tanggapan dari para ahli. Dari penelitian ini ditemukan bahwa permasalahan pariwisata halal berdasarkan tingkat signifikansinya adalah sebagai berikut: Lingkungan, Akses dan Pelayanan, dan Komunikasi. Sedangkan aspek prioritas peningkatan pariwisata halal berdasarkan tingkat signifikansinya adalah lingkungan, akses, pelayanan, dan komunikasi. Serupa dengan permasalahan dan aspek, solusi untuk meningkatkan potensi pariwisata halal berdasarkan tingkat signifikansinya adalah lingkungan, akses, pelayanan dan komunikasi. Selain itu, tiga strategi teratas yang direkomendasikan dari studi ini adalah ekosistem, destinasi, serta aksesibilitas dan konektivitas. Temuan penelitian ini juga dilengkapi dengan beberapa rekomendasi dari perspektif industri dan stakeholder pariwisata halal.
\end{abstract}

Kata kunci: Pariwisata halal, Analytic Network Process, Sumatera Utara, Danau Toba

\footnotetext{
1 Universitas Islam Negeri Sumatera Utara Medan | hefriansyah22ry@gmail.com

2 Universitas Islam Negeri Sumatera Utara Medan | asmuni@uinsu.ac.id

3 Universitas Islam Negeri Sumatera Utara Medan | Muslim.marpaung07@gmail.com

${ }^{4}$ Universitas Ibn Khaldun Bogor | hendri.tanjung@gmail.com
} 


\section{Introduction}

Halal tourism is currently a popular theme within tourism industry not only in Indonesia but also around the world. Halal tourism is also becoming an important part of the global Islamic economic agenda to enhance practices of the alal industry ecosystem (Samori, Shalleh, \& Khalid, 2016). Indonesia has huge potentials and economic prospects in this industry. Tourism industry is intended to provide material and psychological aspects toward tourists themselves as well as contributing to increase the government revenue. However, halal tourism is not intended to be exclusive, but be more inclusive to all tourists (either Muslim and non-Muslim). The core principle of halal tourism emphasizes sharia management in their services, which are polite and friendly to all tourists and to all surrounding environment. Therefore, in order to establish Indonesia as the core/qibla of the world halal tourism, development strategy is required to enhance the competitiveness index as main indicators of halal tourism, for instance by providing suitable and comfortable infrastructure, developing qualified human resource in travel business and sharia matter, doing massive promotion to all over the world, and lastly enhancing the capacity of tourism industry (Jaelani, 2017).

Indonesia acquired more than 10 awards in World Halal Tourism Award competition 2016 in Abu Dhabi. According to Tourism Minister of Indonesia Republic, Arief Yahya, this victory will be the beginning to construct a new halal tourism ecosystem in Indonesia, which will contribute to a major achievement of tourist visit targets (Jaelani, 2017). The awards in the World Halal Tourism Awards 2016 with 12 categories won by Indonesia are including the best airline for halal travellers in the world (Garuda Indonesia), the best airport for halal travellers in the world (Sultan Iskandar Muda International Airport), the best family friendly hotel (The Rhadana Hotel, Kuta, Bali, Indonesia), the Most Luxurious Family Friendly Hotel (Trans Luxury Hotel Bandung Indonesia), the Best Halal Beach Resort (Novotel Lombok Resort \& Villas, Lombok, NTB), the World's Best Halal Tour Operator (Ero Tour, West 
TIFBR | Tazkia Islamic Finance and Business Review

Volume 14(1), 2020

Sumatera Indonesia), the Best Halal Tourism Website (www.wonderfullomboksumbawa.com,Indonesia), the Best Halal Honeymoon Destination (Sembalun Village Region,Lombok, Nusa Tenggara Barat, Indonesia), the Best Hajj \& Umrah Operator (ESQ Tours \& Travel, Jakarta, Indonesia), the best Halal Destination (West Sumatera, Indonesia), the Best Halal Culinary Destination: West Sumatera, Indonesia; and and lastly, the Best Halal Cultural Destination: Aceh, Indonesia.

Jaelani (2017) mentioned that Indonesia has a good potential and prospect of halal travel and tourism. Meanwhile, Deputy Chief of Nusantara Tourism Development and Promotion, Esthy Reko Astuty asserts, there are many reasons why Indonesia can become the centre for halal tourism in the world. To begin with, Indonesia has started to encounter many world tourism attractions that are equipped with such convenience facilities and worth services, for instance international standard hotels, international standard restaurants, etc. For another thing is accessibility such as international and domestic standard airport, and standard infrastructure with human friendly. Moreover, halal tourism product is an alternative to tourism product. This means that every tourist can also take advantage from those various facilities. Halal tourism product is not only intended for middle east tourist but also for all countries, such as Japan, Korea, China, US, UK, etc.

According to Committee for Commercial and Economic Corporation (Comcec) which comes from Turkey, there are three important components to develop halal tourism, namely halal food, masjid/musholla, water-based toilets, facility and services during Ramadhan, non-halal elements facilities, and private recreation facility. The problem that arises related to first component is halal tourism destinations still less commitment to meet the availability of halal restaurant, as well as musholla facility and the availability of toilet. The problem lies in the cleanliness of the place, the availability of facilities for women and maintenance. Services and fulfillment of Ramadhan facilities, facilities that are free from non-halal elements, recreational facilities that are privacy are also not 
maximally fulfilled in halal tourism destinations. For its development, these basic facilities must be met in strategic tourist areas (Comcec, 2016).

Basically, there are four reasons and motivation in a tourism; religious motivation (10 percent), enjoying leisure time (75 percent), business (9-10 percent), and seeking for treatment (less than one percent). However, the weakness from these components is the lack of maximum to introduce Islamic historic sites for Muslim tourists, even though this already became the uniqueness of halal tourism (Comcec, 2016). In addition, other components of halal tourism are closely related to hospital services, other supporting facilities such as transportation availability, accommodation services, travel agency operators, availability of professional human resources, and attractive tourist destinations. In many cases, travel agency operator's promotion target is only focus on outbound traveler not inbound traveler. Outbound traveler means the people is doing travel and stay in somewhere places outside of their residence country for below than 12 months, for example Indonesian do travel to India or China. Otherwise, inbound traveler requires the citizens doing travel to places out of their residence country less than a day or more than a year. The main problem lies in the unavailability of promotional tour packages to inbound tourists. Thus, it is expected that there will be training and education for travel agencies to be able to maximize the existing potential tourism. Likewise, the availability of human resources, it must be empowered and become a major concern in the development of halal tourism (Comcec, 2016).

The problem in developing halal tourism in Indonesia lies in inadequate infrastructure, government awareness, and the availability of investment in the private sector in the development of the tourism industry. The main thing that urgently to be improved from the development of Indonesian halal tourism is the involvement of various parties to promote Indonesian halal tourism to the world. This method is expected able to guarantee the existence of halal tourism market in Indonesia as well as the existence of traditional tourism markets (Comcec, 2016). 
Government trough Government Regulation, Republic of Indonesia, No 50 year 2011 about National Tourism Development Master Plan (Rencana Induk Pembangunan Kepariwisataan Nasional/RIPARNAS) year 2010-2015, has established 50 national tourism destinations (Destinasi Pariwisata Nasional/DPN), 88 national tourism strategic areas (Kawasan Strategis Pariwisata Nasional/KSPN), and 222 national development areas (Kawasan Pengembangan Nasional/KPPN). Among those 50 DPNs, 10 priority tourism destinations (DPP) have been established, namely Borobudur tourism and its surroundings, Mandalika and its surroundings, Labuan Bajo and its surroundings, Bromo-Tengger-Semeru and its surroundings, Kepulauan Seribu and its surroundings, Danau Toba and its surroundings, Wakatobi and its surroundings, Tanjung Lesung and its surroundings, Morotai and its surroundings, amd Tanjung Kelayang and its surroundings. From those ten DPPs as mentioned above, Toba Lake is becoming a top priority tourism destination that must bear special attention due to the area is connected with several districts in North Sumatra Province, for instance, Samosir, Simalungun, Nort Tapanuli, Humbang Hasundutan, Karo, and Toba Samosir. Therefore, the development of tourism requires cross-sectoral hard work. In addition to these factors, the development of Toba Lake priority tourism destinations is also being the central attention of the Governmnet. That attention was contained in Presidential Regulation (Peraturan Presiden/Perpres) No 49 Year 2016 about Toba Lake tourism zone management authority agency.

One important thing that must be carefully considered in the development of Toba Lake tourism is the development of surrounding area, which is including supporting areas such as Pematangsiantar. Therefore, the target to increase visitors to I million people in 2019 by becoming a Toba Lake as main destination in Indonesia can be achieved. Besides, Ayumi (2019) in Crescent Rating on Halal Travel assert that the need of Muslim travelers toward tourism residence must fulfill some criteria; What must be owned, what is good to have, and what should be owned by an explorer area. Indonesia as the $1^{\text {st }}$ rank of halal travel and tourism destination in the world according to the 
Global Muslim Travel Index 2019 holds the potency which must be explored to increase Pematangsiantar city's income (Pendapatan Asli Daerah/PAD).

Pematangsiantar city with 251,519 population in 2017 (Global Muslim Travel Index, 2019) assigned the urgency of developing Pematangsiantar tourism to becoming the main gate toward Toba lake tourism object location as well as other tourism areas. Therefore, Pematangsiantar is popular with transit city (Kota Persinggahan) for visitors. Big holiday is the best time for visitors to visit Toba Lake. In addition, Pematangsiantar city has a strategic geographical location particularly in trading sector, hotel, restaurant, tourism, and agriculture sectors. Therefore, the development of halal tourism in Pematangsiantar city as a supporter of Toba lake destination is completely necessary. The problem arises in the Toba Lake tourism destination area among Muslim travelers recently is lack of halal restaurant information or lack of guaranteed halal restaurants or food shopping centre. Most muslim travelers prefer to purchase food stocks, souvenirs and eat in the restaurant outside the city. Besides, the existing services and facilities in Toba Lake are inadequate, for instance, hospital services, and other supporting facilities such as the availability of transportation terminals, transportation services, accommodation services, travel agency operators, availability of professional human resources and attractive tourist destination. Ancillary factors which include institutional variables, community empowerment and marketing are also less concern. Thus, by those factors as already mentioned above are considered to becoming the causes of the reduction of Toba Lake tourists.

There are some previous studies which have been conducted in the term of halal travel and tourism industries. Pahrul, Irfan and Apriani (2017) introduced e-tourism concept to promote local tourism in Indonesia. Previously, Tresna, et al. (2016) also introduced halal town innovation for tourism, which intended to attract Muslim traveler to visit Non-Muslim countries. Halal town innovation for tourism describes four important things to consider, namely, accommodation, market, tourism package, and halal regulation. Wardani and Nasution (2016) specifically were doing research 
about the contribution of Toba lake tourism development toward society around the city through BOP (Badan Otoritas Pariwisata) scheme. This scheme was allegedly effective to increase social economic well-being of the society. Chanin, et al. (2015) also discussed the management of halal tourism guidelines in Thailand, specific study in Andaman Sea Cost. The finding indicates that halal facilities and infrastructure are the most important things to support halal tourism in Thailand, such as place for worship, masjid, the information in English and Arabic language, toilet which desperate between man and woman, and halal restaurant. Halal tourism study in Indonesia also has been conducted by Andriani, et al. (2015); Winarti (2017); Jaelani (2017); Khoiriati, Krisnajaya, and Dinarto (2018); Devi and Firmansyah (2019); and latest publication by Palupi, Romadhon, and Arifan (2020). Those studies are still need to be developed by constructing compound model which discuss the problems, solutions and strategies to enhance the travel and tourism practices. Consequently, prompt methodology is required in order to get the problem solver.

Hence, still there is lack of study in the term of halal travel and tourism in developing countries, in particular Indonesia. Moreover, confidently to say that still zero literature which is studied in Pematangsiantar city, considering Pematangsiantar is one of the most popular travel and tourism destination in Indonesia. Therefore, in order to support Toba lake tourism, Pematangsiantar city is expected to be able to fulfill and provide several things as mentioned earlier. Moreover, Toba lake visitors also can be introduced by ecotourism and Pematangsiantar natural tourism, such as tour of animal park, flower garden, Avaloskitesvara temple, Simalungun museum, Bah Butong waterfall, Sidamanik tea plantation, and nature baths (East and Karang Anyar). By developing halal tourism in Pematangsiantar, it is expected able to increase tourist tourism destination. This study is aimed to explore problems and offer solutions and strategies in order to develop halal tourism in Pematangsiantar Indonesia. 


\section{Literature Review}

According to the Regulation No.51 year 2015 from West Nusa Tenggara Governor about halal tourism, halal tourism is an agenda of visitation to a tourism destination where tourism industry provides product facility, services and tourism management that meet the sharia elements. Riyanto (2012) asserts that halal tourism definition is more broadly than religious tourism. Halal tourism is a tourism which is under Islamic sharia principles. World Tourism Organization (WTO) stated that the consumers of halal tourism are expected not only coming from Muslims country but also from those who expect to be amused by local wisdom. The owner of Sofyan hotel network explained the general criteria for halal tourism are possessing a calmness, enlightenment, refreshment orientation to visitors, put forward on public good orientation, full respect on social value, cultural value as well as local value, preserving the safety and comfort not only for visitors but also for workers who are in, free from polytheism, khurafat, and immorality, and lastly, care to the environment sustainability. Overall, halal tourism accredits to the providing product and services to visitors which confront the demand of Muslim travellers such as fulfilling the need to worship facility and dietary requirement which relies on Islamic values and teachings (Mohsin, et al., 2016).

The Qur'anic verse which contains information about the tourism to support the increasing of spiritual conditions is as follows; Q.S. Ali Imran [3] : 137, Muhammad [47] : 10, Al-Naml [27] : 69, Al-An'am [6] : 11, An-Nahl [16] : 36, Al-Hajj [22] : 46, Ghaafir [40] : 21. In addition, the Qur'anic verse which contains information about tourism for social purpose is as follows; QS. Yusuf [12] : 109, Al-Rum [30] : 9, Faathir [35] : 44, and Yunus [10] : 22. Moreover, the Qur' anic verse which contains information about tourism for physical reasons is as follows; QS. Al-Mulk [67] : 15, Lukman [31] : 31, Al-'Ankabut [29] : 20 and Saba' [34] : 18 (Shakona, et al., 2014).

For more details, following table describes the difference between halal tourism and other types of tourism. 
Table 1. The Difference between Halal Tourism and Conventional Tourism

\begin{tabular}{|c|c|c|c|c|}
\hline No & $\begin{array}{c}\text { Difference } \\
\text { Object }\end{array}$ & $\begin{array}{l}\text { Conventional } \\
\text { Tourism }\end{array}$ & $\begin{array}{l}\text { Religious } \\
\text { Tourism }\end{array}$ & Halal Tourism \\
\hline 1 & $\begin{array}{l}\text { Culinary } \\
\text { object }\end{array}$ & $\begin{array}{l}\text { Nature, heritage } \\
\text { and culture }\end{array}$ & $\begin{array}{l}\text { Worship/religio } \\
\text { us places, } \\
\text { historical } \\
\text { heritage }\end{array}$ & All \\
\hline 2 & Purposes & Entertainment & $\begin{array}{l}\text { Increasing } \\
\text { spiritual aspect }\end{array}$ & $\begin{array}{l}\text { Increasing spiritual and } \\
\text { religiosity through entertainment }\end{array}$ \\
\hline 3 & Target & $\begin{array}{l}\text { Solely for } \\
\text { entertainment } \\
\text { (satisfying lust } \\
\text { for pleasure and } \\
\text { satisfaction) }\end{array}$ & $\begin{array}{l}\text { Mastering a } \\
\text { spiritual which } \\
\text { can please and } \\
\text { calm the soul }\end{array}$ & $\begin{array}{l}\text { Fulfilling the desires and } \\
\text { pleasures as well as fostering } \\
\text { awareness of a belief in life and } \\
\text { personal survival }\end{array}$ \\
\hline 4 & Tour Guide & $\begin{array}{l}\text { Understanding } \\
\text { and mastering } \\
\text { all tourism } \\
\text { information and } \\
\text { able to explain } \\
\text { to tourist as well } \\
\text { as possible }\end{array}$ & $\begin{array}{l}\text { Mastering the } \\
\text { history of } \\
\text { figures and } \\
\text { locations of a } \\
\text { tourist } \\
\text { attractions }\end{array}$ & $\begin{array}{l}\text { Create interest of tourist toward } \\
\text { tourism objects as well as increase } \\
\text { the spirit of ethical life awareness, } \\
\text { able to demonstrate the functions } \\
\text { and roles of sharia, and deliver } \\
\text { the explanation as attractive as } \\
\text { possible. By doing this, tourist } \\
\text { able to understand sharia role in } \\
\text { the term of inner satisfaction and } \\
\text { happiness }\end{array}$ \\
\hline No & $\begin{array}{c}\text { Difference } \\
\text { Object }\end{array}$ & $\begin{array}{l}\text { Conventional } \\
\text { Tourism }\end{array}$ & $\begin{array}{l}\text { Religious } \\
\text { Tourism }\end{array}$ & Halal Tourism \\
\hline 5 & $\begin{array}{l}\text { Worship } \\
\text { facilities }\end{array}$ & $\begin{array}{l}\text { Just a } \\
\text { complement }\end{array}$ & $\begin{array}{l}\text { Included in the } \\
\text { trip }\end{array}$ & $\begin{array}{l}\text { Becoming an essential part in the } \\
\text { tourism activities, sometimes, } \\
\text { ritual worship becomes an } \\
\text { entertainment package }\end{array}$ \\
\hline 6 & Culinary & General & General & $\begin{array}{l}\text { Specific. } \\
\text { Unlawful elements (haram } \\
\text { materials for food) are not } \\
\text { contained in the culinary. }\end{array}$ \\
\hline 7 & $\begin{array}{l}\text { Social/com } \\
\text { munity } \\
\text { relationship }\end{array}$ & $\begin{array}{l}\text { Complementary } \\
\text { and purely for } \\
\text { profit }\end{array}$ & $\begin{array}{l}\text { Complementary } \\
\text { and purely for } \\
\text { profit }\end{array}$ & $\begin{array}{l}\text { Integrated and interacting based } \\
\text { on sharia principles }\end{array}$ \\
\hline 8 & $\begin{array}{l}\text { Travel } \\
\text { agenda }\end{array}$ & $\begin{array}{l}\text { Disregarding } \\
\text { time, solely for } \\
\text { the sake to } \\
\text { pursue the } \\
\text { profit }\end{array}$ & $\begin{array}{l}\text { Complementary } \\
\text { to pursue profit }\end{array}$ & $\begin{array}{l}\text { Integrated and interacting based } \\
\text { on sharia principles }\end{array}$ \\
\hline
\end{tabular}

Source: Sucipto and Andayani (2014)

According to the table above, it is clear that there are some differences between halal tourism and other types of tourism. Halal tourism emphasizes on the implementation and fulfillment of sharia elements in every single of activity or tourism activity. Unlawful elements in Islam are extremely intolerable in halal tourism. This aspect becomes the main advantages of halal 
tourism that are not possessed by other types of tourism. Islamic law always binds all tourists Muslim activities in halal tourism. There are some aspects that urgently to be considered in halal tourism, namely, hijab (to separate between male and female, it might be area, toiletries, place for worship, etc.), the availability of worship area, halal culinary/food, the existence of mahram for women visitors, the obligation to cover aurah, etc.

\section{Methods}

This study employs Analytic Network Process (ANP) method which provides relative measurement to some selected aspects/elements. ANP is also applied to create a complex priority which is indicated by the scale ratio from individual perspective and compounded to get global ratio. The ratio represents a relative measurement toward some interconnected aspects/elements in the model. ANP methodology was firstly developed by Saaty in 1996, which previously popular with AHP (Analytic Hierarchy Process). ANP allows one variable to systematically compromise with dependence, feedback, and loop path to acquire and combine both tangible and intangible elements by employing 9 ration scale.

ANP is known as a new method which provides a general framework for decision making process which does not require any assumption on the independency variables in higher level from variables in a lower level and on the independent variables within the same level (Ascarya and Yumanita, 2006; Tanjung and Devi, 2013). Another benefit from the ANP model is that it does not encounter some statistical problems, such as normality, multicollinearity, as well as a common problem which is commonly faced by an econometric model in the same process. Nevertheless, the ANP model has a conceptual foundation which matches to traditional complex indicator methods. ANP is also a method which is suitable to be applied toward a wider spectrum in an economic process activity (Saaty and Vargas, 2006).

The ANP model applies the primary data through several steps, namely model decomposition through literature review and in-depth interview, model 
quantification via pair-wise questionnaire and synthesis and analysis. The initial variables were derived from the halal tourism literature, which is then used to decompose the ANP framework. The draft of the ANP framework was subsequently confirmed via in-depth interview. The number of respondents in this study is comprised into 5 (five) most knowledgeable people in the field of halal tourism from three main categories, practitioners (the owner of sharia/halal hotel), regulator (DPRD/regional people's representative assembly and MUI/Indonesia Ulama Council), and academia (lectures and researchers). Normally, Mishra (2016) stated that Focus Group Discussion (FGD) can be conducted by collecting 10 to 12 respondents/informants which is guided by moderator. On the other hand, Dilshad and Latif (2013) contend 6 to 12 people to be included in the FGD participants. However, ANP requires most qualified and knowledgeable people as participant instead of considering the quantity of respondent. Therefore, 5 selected people is expected can provide the most acknowledgeable and powerful opinion in the term of halal travel and tourism in Pematangsiantar.

Overall, the expert respondents in this study are selected based on the following criteria: (a) The expert has vast experience in the tourism industry in Indonesia, particularly in Pematangsiantar and deals directly with the tourism industry agenda. (b) The expert has deep knowledge and understanding about theory and practice of halal tourism. (c) The expert from academics and regulators in particular regularly publish their research/work on tourism industry.

After conducting the synthesis of ANP, the last step from this mixmethod is calculating the rater agreement among respondents. By doing this, the priority can be analyzed more broadly especially in identifying the agreement of the respondents. Rater agreement is the measurement which shows the agreement rater among respondents ( $R 1$ to $R n$ ) toward elements in a cluster. Kendall's Coefficient of Concordance method is employed to calculate the rater agreement in ANP. The value of rater agreement symbolized by $\mathrm{W}$, where $W=0 \leq 1$. If $W$ value displays 1 means that the respondents are totally 
agreed to the case, otherwise, 0 indicates that the respondents are totally disagreed to the case.

\section{Results and Discussions}

\section{Model Decomposition}

This section presents the finding and analysis of the ANP on the identifying the problematic analysis of the halal tourism development in Pematangsiantar city Indonesia. The first part is delivering the model construction of the ANP. Following figure describes detail ANP model.

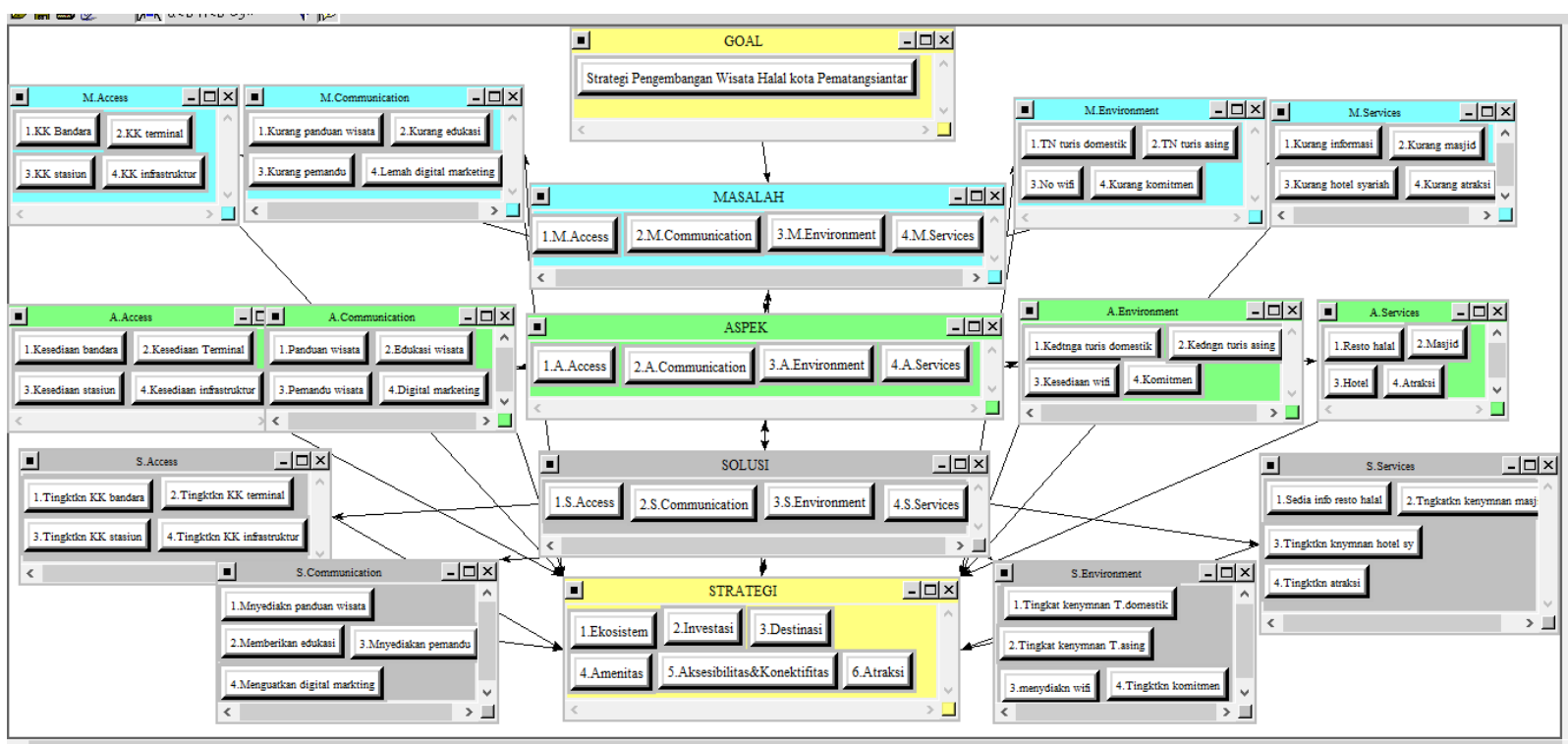

Figure 1. ANP Model Construction

Based on the in-depth interview and study literature results, this study develops the ANP model in four levels, namely, problems, aspects, solutions, and strategies (figure 1). The problems identified in this study include access, communication, environment, and services. Aspects cluster and solutions are also identified into four sub clusters, namely access, communication, environment, and services. Meanwhile, strategies are divided into 6 (six) elements, namely ecosystem, investment, destination, amenity, accessibility and connectivity, and attraction. Each sub cluster for sub problems, sub aspects, and sub solutions also divided into four elements. Access problem has four elements, include (1) Airport eligibility and availability; (2) Bus station 
eligibility and availability; (3) Train station eligibility and availability; and (4) Infrastructure availability. Communication problems also has four elements; (1) Lack of travel guidance for Muslim; (2) Lack of halal travel education for stakeholder; (3) Lack of tour guide and (4) Weak of marketing digital. Environment problems divided into four elements, namely, (1) The inconvenience of domestic tourist arrivals; (2) The inconvenience of foreign tourist arrivals; (3) The absence of Wi-Fi; and (4) Lack of commitment. Services problems has four elements as well; (1) Lack of halal resto information; (2) Lack of comfort and availability of masjid; (3) Lack of comfort and information of sharia hotel; and (4) Lack of Muslim attraction.

Access aspect has four elements, include (1) Airport eligibility and availability; (2) Bus station eligibility and availability; (3) Train station eligibility and availability; and (4) Infrastructure availability. Communication aspect also has four elements; (1) Travel guidance for Muslim; (2) Halal travel education for stakeholder; (3) Tour guide and (4) Marketing digital. Environment aspect divided into four elements, namely, (1) Domestic tourist arrivals; (2) Foreign tourist arrivals; (3) The availability of Wi-Fi; and (4) Commitment. Services aspect has four elements as well; (1) Halal resto information; (2) Masjid; (3) Sharia hotel; and (4) Muslim attraction.

Access solution has four elements, include (1) Improving airport eligibility and availability; (2) Improving bus station eligibility and availability; (3) Improving train station eligibility and availability; and (4) Improving infrastructure availability. Communication solution also has four elements; (1) Providing travel guidance for Muslim; (2) Providing halal travel education for stakeholder; (3) Providing tour guide and (4) Strengthening marketing digital. Environment solution divided into four elements, namely, (1) Improving domestic tourist arrivals comfortable; (2) Improving foreign tourist arrivals comfortable; (3) Improving the availability of Wi-Fi; and (4) Improving halal travel commitment. Services solution has four elements as well; (1) Improving halal resto information; (2) Improving masjid eligibility and availability; (3) 
Improving sharia hotel eligibility and availability; and (4) Improving Muslim attraction.

\section{Model Quantification}

This section presents the results or synthesis of ANP network which derived from the computation result of super decision software. The computed data is exported to excel worksheet to produce the expected outputs. Afterwards, a geometric mean/average of all respondents' responses is calculated and re-synthesized to produce scientific 'consensus' result analysis.

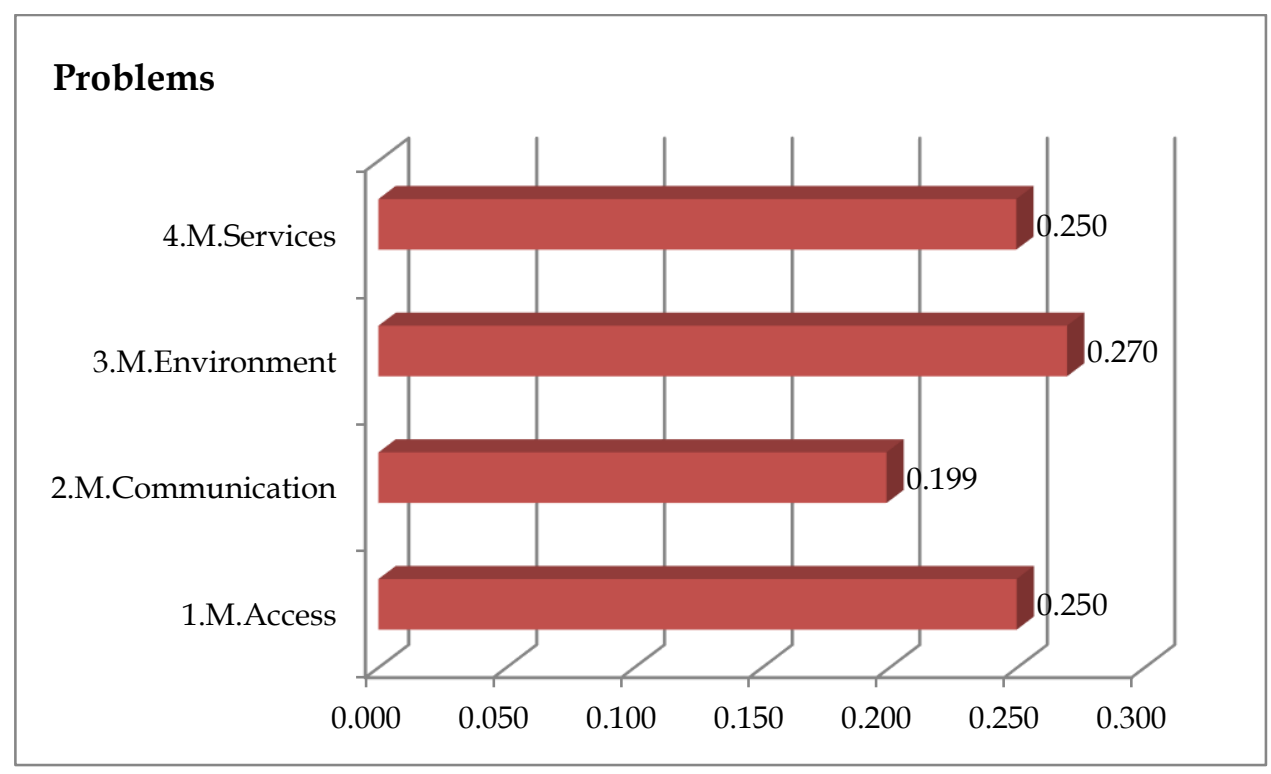

Figure 2. Geometric Mean of Problem Cluster

The overall ANP results (figure 2) show that the problems to develop halal tourism in Pematangsiantar, Indonesia on the level of importance are environment, followed by services and access (which has the same weight of priority), and communication. The acquisition of $W$ (rater agreement) value is 0.116 which signifies that all respondent has relatively divergent views on the priority of problem cluster. In details, following figure shows the priority of all sub clusters from problem clusters. 


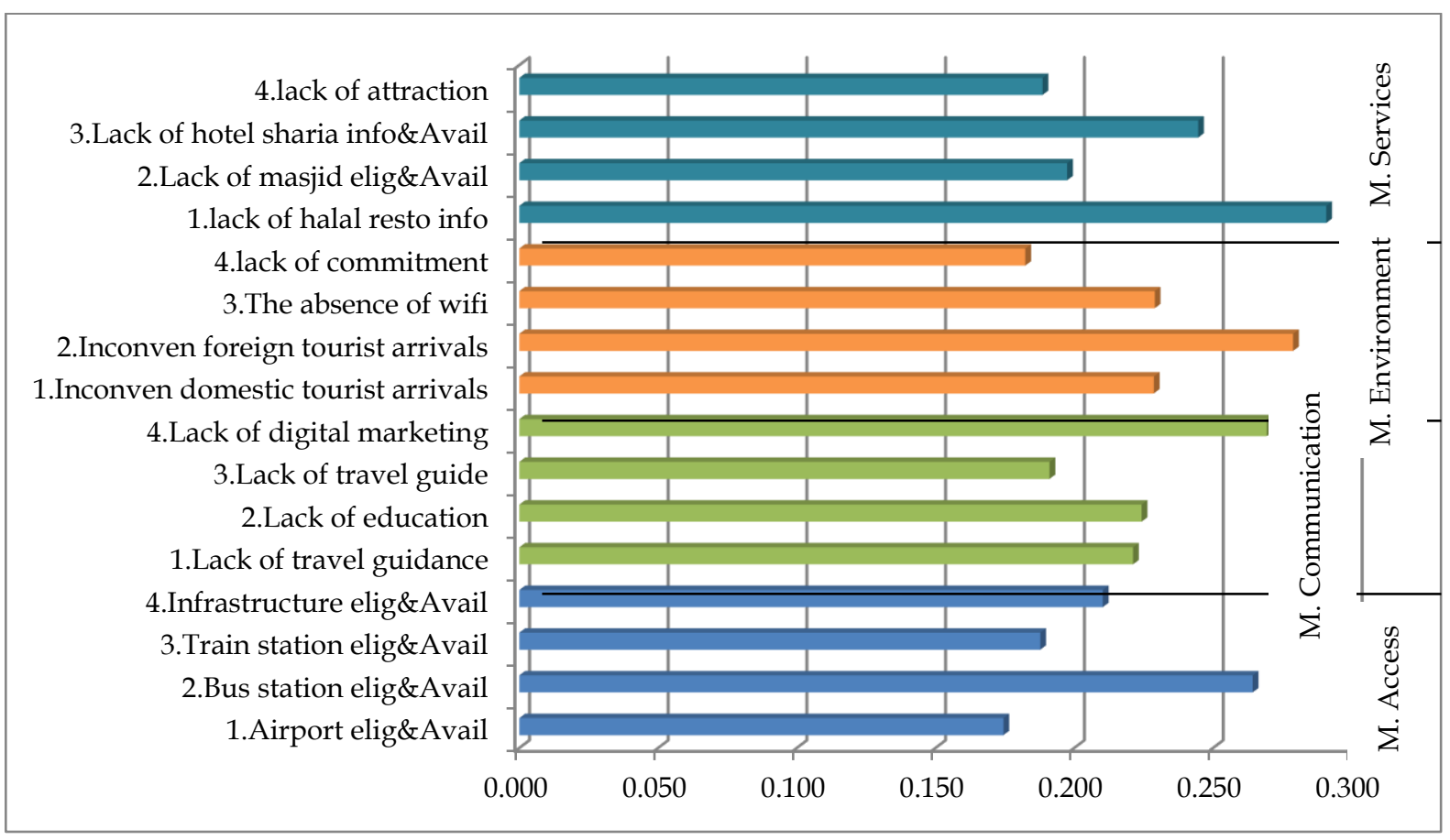

Figure 3. Geometric Mean of Sub Problem Clusters

Figure 3 also presents ANP analysis of the sub problem cluster (sub cluster of access, communication, environment, and services). According to its priority, bus station eligibility and availability takes the highest priority of access problem, followed by infrastructure eligibility and availability, train station eligibility and availability and airport eligibility and availability stands as the last priority. Meanwhile, communication problem sub cluster illustrate the information that lack of digital marketing takes the highest priority of the problem, followed by lack of education on halal travel and tourism, lack of travel guidance, and lack of travel guide. On the other side, environment cluster provides priority information, namely, inconvenience foreign tourist arrivals take the highest priority of the problem, followed by inconvenience domestic tourist arrivals and the absence of Wi-Fi which have the same weight of priority, and lack of halal travel and tourism commitment stands as the last priority. Lastly, figure 3 provides priority information of services problem where lack of halal resto information takes the highest priority of the problem, followed by lack of hotel sharia eligibility and availability, lack of masjid 
eligibility and availability, and lack of attraction. The next ANP result is Aspect cluster which will be presented through following figure:

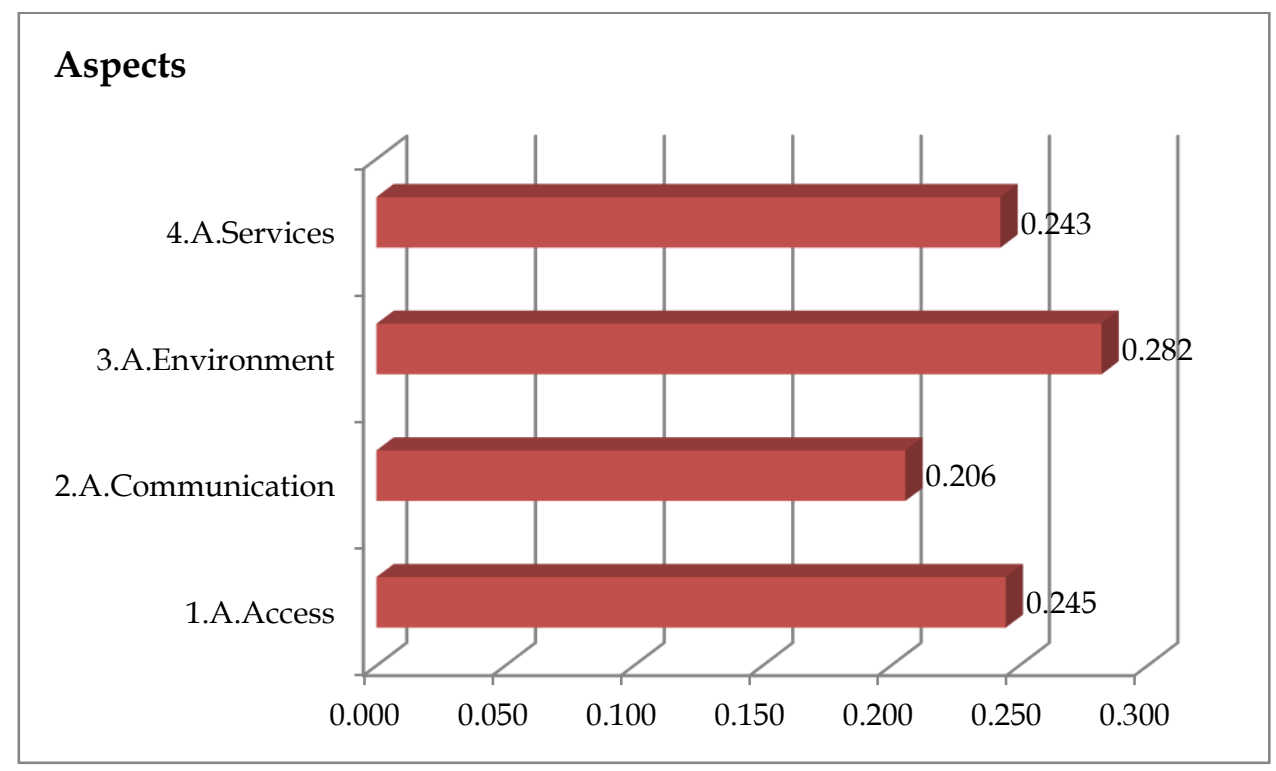

Figure 4. Geometric Mean of Aspect Cluster

The overall ANP results (figure 4) show that the aspects to develop halal tourism in Pematangsiantar, Indonesia on the level of importance are environment, followed by access, services and communication. The acquisition of $\mathrm{W}$ (rater agreement) value is 0.04 which signifies that all respondent has relatively divergent views on the priority of aspect cluster. In details, following figure shows the priority of all sub clusters from aspect clusters. 


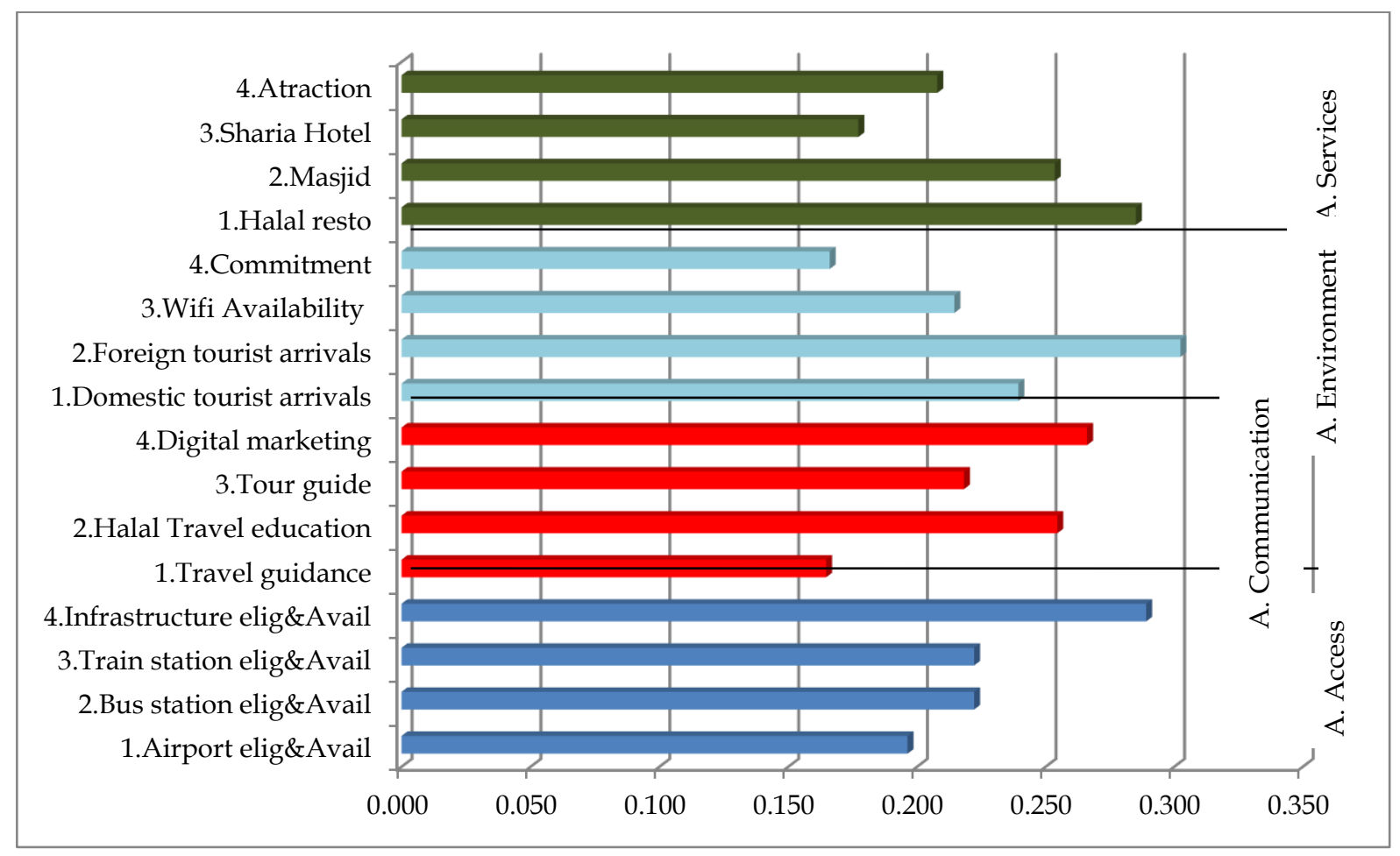

Figure 5. Geometric Mean of Sub Aspect Clusters

Figure 5 also presents ANP analysis of the sub aspect cluster (sub cluster of access, communication, environment, and services). According to its priority, infrastructure eligibility and availability takes the highest priority of access aspect, followed by train station eligibility and availability and bus station eligibility which has the same weight of priority and availability and airport eligibility and availability stands as the last priority. Meanwhile, communication aspect sub cluster illustrates the information that digital marketing takes the highest priority of the aspect, followed by education on halal travel and tourism, tour guide and travel guidance. On the other side, environment cluster provides priority information, namely, foreign tourist arrivals take the highest priority of the aspect, followed by domestic tourist arrivals, Wi-Fi availability and halal travel and tourism commitment stands as the last priority. Lastly, figure 5 provides priority of services aspect where halal resto information takes the highest priority of the aspect, followed by masjid, attraction, and sharia hotel. The next ANP result is solution cluster which will be presented through following figure: 


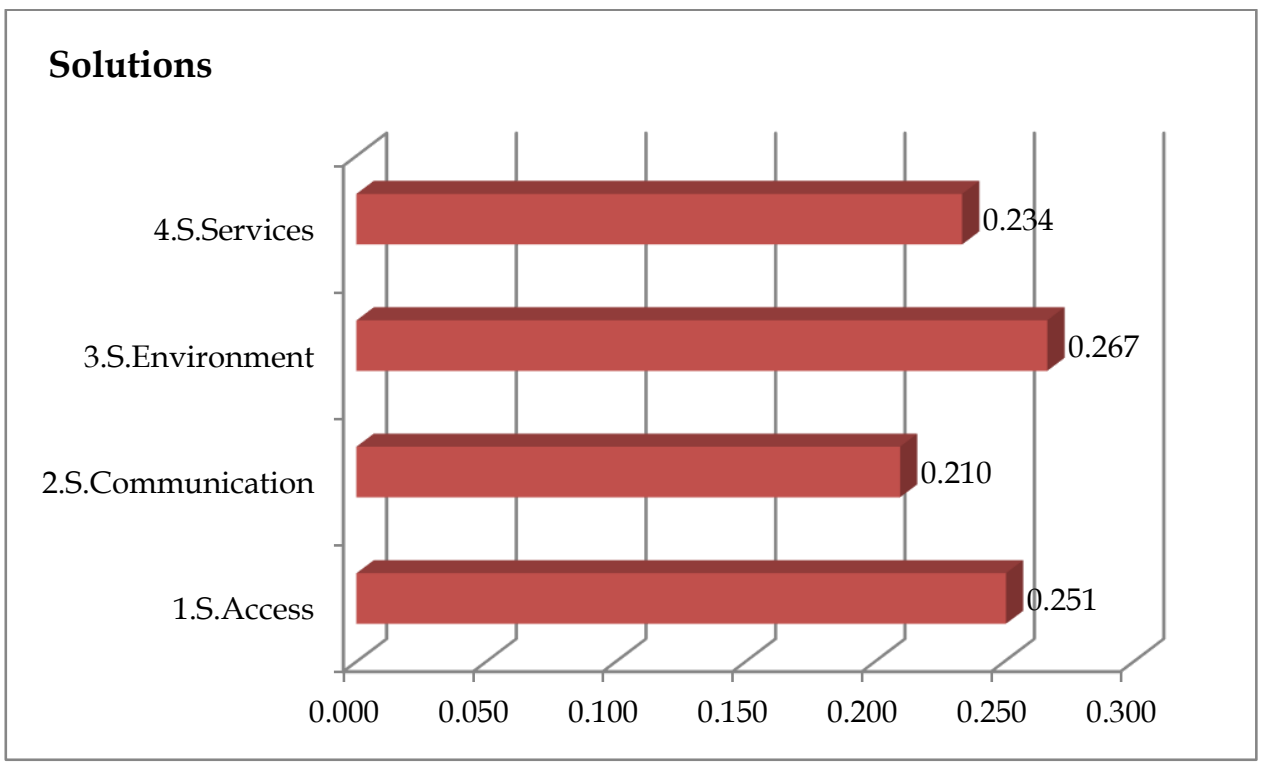

Figure 6. Geometric Mean of Solution Cluster

The overall ANP results (figure 6) show that the solutions to develop halal tourism in Pematangsiantar, Indonesia on the level of importance are environment, followed by access, services and communication. The acquisition of $\mathrm{W}$ (rater agreement) value is 0.052 which signifies that all respondent has relatively divergent views on the priority of solution cluster. In details, following figure shows the priority of all sub clusters from solution clusters. 


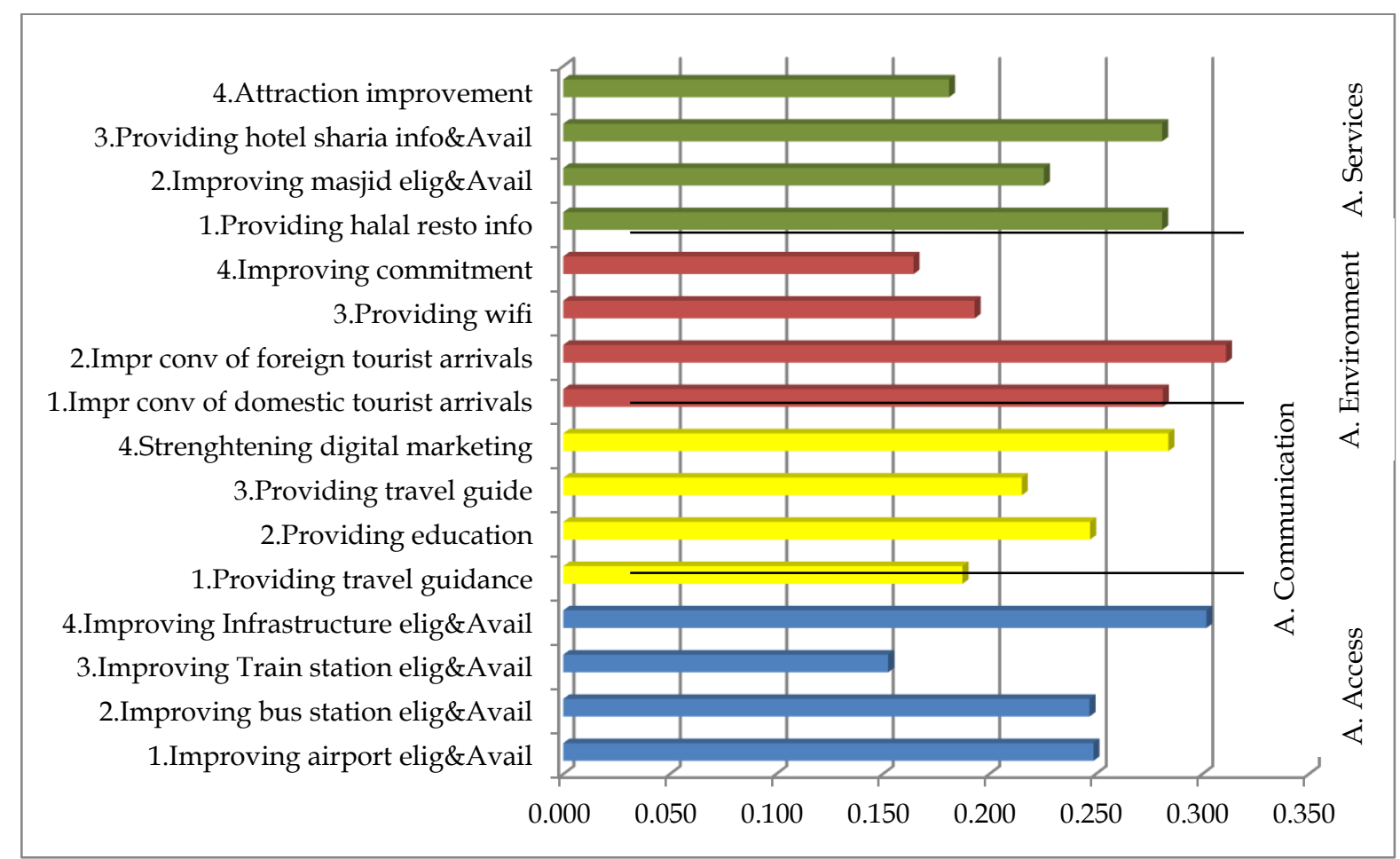

Figure 7. Geometric Mean of Sub Solution Clusters

Figure 7 also presents ANP analysis of the sub solution cluster (sub cluster of access, communication, environment, and services). According to its priority, improving infrastructure eligibility and availability takes the highest priority of access solution, followed by improving airport station eligibility and availability, improving bus station eligibility and availability and improving train station eligibility and availability stands as the last priority. Meanwhile, communication solution sub cluster illustrates the information that strengthening digital marketing takes the highest priority of the solution, followed by providing education on halal travel and tourism, providing tour guide and providing travel guidance. On the other side, environment cluster provides priority information, namely, improving convenience of foreign tourist arrivals takes the highest priority of the solution, followed by improving convenience of domestic tourist arrivals, providing Wi-Fi and improving halal travel and tourism commitment stands as the last priority. Lastly, figure 7 provides priority of services solution where providing hotel sharia and halal resto information takes the highest priority of the solution, followed by improving masjid eligibility and availability, and attraction improvement. The 
next ANP result is strategy cluster which will be presented through following figure:

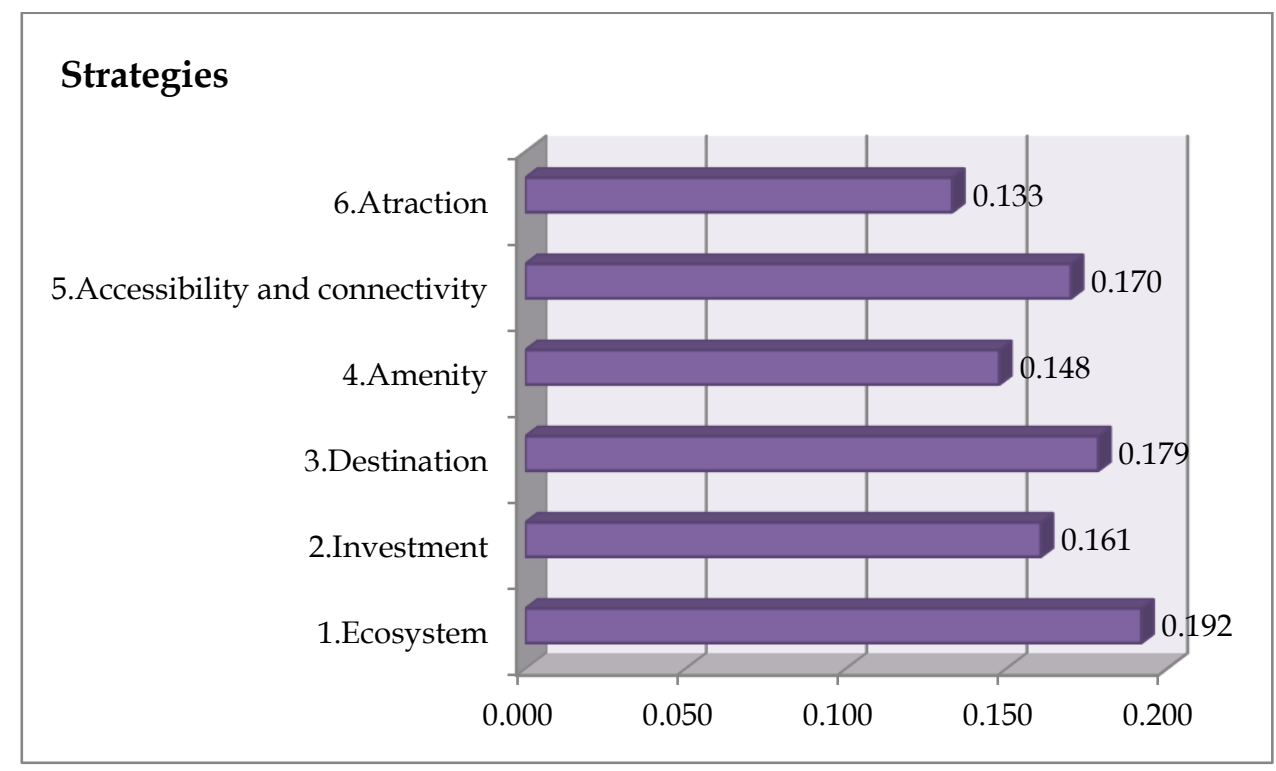

Figure 8. Geometric Mean of Strategy Cluster

The last result (figure 8) provides information on selected strategies to develop halal tourism in Pematangsiantar, Indonesia. According to the level of importance, the top strategy is building a halal ecosystem, followed by destination, accessibility and connectivity, investment, amenity, and attraction. The acquisition of $\mathrm{W}$ (rater agreement) value is 0.269 which signifies that all respondent has relatively divergent views on the priority of solution cluster.

As confirmed, according to the finding, it can be concluded that two main problems to develop halal tourism in Pematangsiantar are environment problems, services and access. Both services and access have the same priority based on respondent's perspective. This finding closely correlate with previous study by Mohsin, et al. (2016) also addresses the issue of the importance of halal certification to protect customer from unlawful material particularly for food. Halal certification must be produced by local government and local authorized association bodies. Consumer protection is part of halal tourism environment where basically defined as creating halal ecosystem based on Islamic teachings and values. In order to improve the services of halal tourism, clear and detail information on some of facilities are extremely important. One of the recent 
practices is the existence of smartphone application can make more enjoyable holiday and also Muslim friendly. Lefevre (2015) identified that as one of nonMuslim country, Thailand took initiatives to adopt and launch Muslim friendly application through mobile phone to develop tourism industry in Thailand proliferated greatly. Another study by Nugraha (2018) also stated the same thing that online information was being the most important thing for traveler to choose the best place to visit. For another thing, Puangniyom, et al. (2017) also stated that local culture was the most important aspect to promote halal travel and tourism in a country. Local culture also can be developed through supportive Islamic environment.

Hjalanger and Richards (2002); Awan, Siddiquei, and Haider (2014); Ab, Hamid and Zulfakar (2015); Nakyinsige, et al. (2012); Riaz and Chaudry (2004); recommend local cuisines as the primary differentiation for the destination in order to compete with other countries. Therefore, if halal tourism make halal food as one of halal criteria, it can be a uniqueness of halal tourism. Mohsin, et al. (2016) also addresses the issue of halal food importance as one of criteria in halal tourism. Muslim tourists are intended by their religion and faith to obey certain religious stipulation in their consumption. Therefore, halal tourism product and services need to be suitable-designed for Muslim travelers under Islamic teaching and values.

More broadly, Yousaf and Xiucheng (2018) also suggests some indicators of featured halal cuisines and restaurants, such as introduction to halal food menu and recipes, recommended halal food restaurants, introduction to local and international halal cuisines available, links to halal food restaurants, shops and brands, restaurant guidebooks for Muslim tourist, categorization of food "halalness", and testimonials of Muslim travelers. In addition, Yousaf and Xiucheng (2018) also suggests some additional feature of halal services and facilities include promoting hotel with halal facilities, special site seeing sports for Muslim tourists, and information about prayer rooms, masjids and ritual washing area. Halal hotel for Muslim also must generated and inserted to the destination program of halal tourism which is not serving 
alcohol beverages, pork and ensuring that halal food are well-provided (Battour and Islmail, 2016; Ramli and Zawami, 2017; Cetin and Dincer, 2016; Winget and Tumbull, 2017).

Recently, Yousaf and Xiucheng (2018) studied preliminary analysis on halal tourism marketing strategies particularly on culinary aspect through government websites. They assert that halal tourism and culinary can be promoted through website. Besides, providing halal services are also important to enhance the existence and availability of halal tourism. Devi and Firmansyah (2019) propose that halal marketing as determinant factor to improve halal travel and tourism in Indonesia. Additionally, authors also suggest the important role of relevant stakeholders, particularly government/local authorities to develop halal travel and tourism by employing massive promotion, socialization and enhancing halal tourism literacy for a wider traveler's segmentation.

Further, massive and comfortable transportation for traveler is being another important aspect to develop halal travel and tourism in Pematangsiantar. Some studies also address the issue of access through the availability of transportation such to support halal travel and tourism development such as Saidi and Hammami (2011); Daniels, et al. (2005); Gubbins (2005); Gunasekaran and Ngai (2003); as well as Ab, Hamid and Zulfakar (2015). Ab, Hamid and Zulfakar (2015) sounded the same thing where the key success of halal travel and tourism development is the availability of dedicated asset (public transportation) either from government or private institution to help traveler reach the travel place easier and comfortable. Saidi and Hammami (2011) also stated that the benefit of transportation is not only focusing to move product from one place to another, but also being the best strategy to attract foreign investment directly. Daniels (2005) also asserts the transportation in the tourism area is not only intended to fulfill the need of common traveler, but also disability-friendly.

Therefore, according to the finding of this study, all stakeholders of Pematangsiantar city including government, practitioners, and academia 
should start to synergize with each other to overcome the problem of halal travel and tourism development. By doing these, the increase number of tourists both foreign and domestic traveler can be reached. Besides, the aim to create the Lake Toba become one of the halal tourism destinations in Indonesia also can be achieved properly.

\section{Conclusion}

The study presented the finding of the problematic analysis of the halal tourism development in Pematangsiantar, North Sumatera, Indonesia based on the ANP approach. The study found that problems and issues in the halal tourism development in North Sumatera, and in particular Pematangsiantar, is derived from four problems based on their level of significance are environment, access and services, and communication. The aspects that must be considered by tourism stakeholders as its priorities are, environment, access, services, and communication. While simultaneously, following priorities on solutions cluster are environment, access, services, and communication. While other part like sub cluster of environments as the top priority of problem cluster presents inconvenience foreign tourist arrivals as the top priority, and lack of commitment as the last priority. Additionally, sub cluster of environments as the top priority of aspect cluster presents foreign tourist arrivals as the top priority, and commitment also stands as the last priority. In line with problem and aspect, sub cluster of environments as the top priority of solution cluster presents improving convenience foreign tourist arrivals as the top priority, and lack of commitment as the last priority. Finally, top three strategies to improve halal tourism in this part of Indonesia are as follows; ecosystem, destination, and accessibility and connectivity.

The study suggests that the halal tourism agenda should focus on minimizing the inconvenience of both foreign and domestic tourist arrivals by providing more extensive and exclusive facilities in particular for Muslim travelers. For instance, government should improve infrastructure transportation eligibility and availability from airport, bus station, and train 
station. The owner of tourism business also can provide even more main product and services such as providing travel guide who expertly understand about halal tourism as a whole, providing detail information about hotel sharia, halal resto, wifi, toilet facilities, worship area, etc. Additionally, tourism business owner also can improve their attraction which is suitable to sharia. By inserting those strategies and activities into halal tourism development agenda in North Sumatera is considered able to improve and strengthen halal tourism, especially in Toba Lake and other destinations.

\section{References}

Ab Talib, M. S., Hamid, A. B. A., \& Zulfakar, M. H. (2015). Halal Supply Chain Critical Success Factors: A Literature Review. Journal of Islamic Marketing.

Andriani, D, et al. (2015). Laporan Akhir Kajian Pengembangan Wisata Syariah, Deputi Bidang Kelembagaan Kepariwisataan Kementerian Pariwisata.

Awan, H. M., Siddiquei, A. N., \& Haider, Z. (2015). Factors Affecting Halal Purchase Intention - Evidence from Pakistan's Halal Food Sector. Management Research Review, Vol. 38(6): 640-660.

Battour, M., \& Ismail, M. N. (2016). Halal Tourism: Concepts, Practises, Challenges and Future. Tourism management perspectives, Vol. 19: 150154.

Cetin, G., \& Dincer, M. Z. (2016). Muslim Friendly Tourism (MFT): A discussion. Journal of Tourismology, Vol. 2(1): 65-67.

Chanin, Oraphan et. al., (2015). Guidelines on Halal Tourism Management in The Andaman Sea Coast of Thailand. Journal of Economics, Business and Management, Vol. 3(8).

Comcec. (2016). Muslim Friendly Tourism: Understanding the Demand and Supply Sides In the OIC Member Countries, (Turkey: Comcec Coordination Office).

Daniels, M.J., E. B. Drogin Rodgers, B. P. Wiggins. (2005). “<<Travel Tales >>: An Interpretive Analysis of Constraints and Negotiations to Pleasure Travel as Experienced by Persons with Physical Disabilities," in Tourism Management, Vol. 26: 919-930.

Devi, A., \& Firmansyah, I. (2019). Developing Halal Travel and Halal Tourism to Promote Economic Growth: A Confirmatory Analysis. Journal of Islamic Monetary Economics and Finance, Vol. 5(1): 193-214. 
Gunasekaran, A., \& Ngai, E. W. T. (2003). The Successful Management of a Small Logistics Company. International Journal of Physical Distribution $\mathcal{E}$ Logistics Management, Vol. 33(9): 825-842.

Hidayat, N. (2016). Bio Proses Limbah Cair, Yogyakarta: Andi Offet.

Hijalanger, A.M., \& Richards, G. (2002). Tourism and gastronomy. Abingdon. Routledge.

Jaelani, A. (2017). Halal Tourism Industry in Indonesia: Potential and Prospects. International Review of management and Marketing, Vol. 7(3): 25-34.

Khoiriati, S. D., Krisnajaya, I. M., \& Dinarto, D. (2018). Debating Halal Tourism Between Values and Branding: A Case Study of Lombok, Indonesia. KnE Social Sciences: 494-515.

Lefevre, A. S. (2015). Thailand Launches Muslim-friendly Tourist App. (Retrieved fromhttp://www.reuters.com/article/2015/06/29/usthailand-tourism-idUSKCN0P918F20150629).

Mohsin, A., Ramli, N., \& Alkhulayfi, B.A. (2016). Halal Tourism: Emerging Opportunities. Tourism Management Perspectives, Vol. 19: 137-143.

Nakyinsige, K., CheMan, Y.B. \& Sazili,A.Q. (2012). Halal Authenticity Issues in Meat and Meat Products. Meat Science, Vol. 91(3): 207-214.

Nugraha, Y.M. (2018). Analisis Potensi Promosi Pariwisata Halal Melalui EMarketing di Kepulauan Riau. Jurnal Penelitian dan Karya Ilmiah Lembaga Penelitian Universitas Trisakti, Vol. 3(2): 63-68.

Pahrul, Irfan \& Apriani. (2017). Analisa Strategi Pengembangan E-Tourism Sebagai Promosi Pariwisata di Pulau Lombok. Jurnal ILKOM Jurnal Ilmiah, Vol. 9(3).

Palupi, M., Romadhon, R. W., \& Arifan, N. (2020). The Importance of Optimization of Halal Tourism: A Study of the Development of Halal Tousrism in Indonesia. In Proceedings of the 29th International Business Information Management Association Conference-Education Excellence and Innovation Management Through Vision: 3083-3092.

Puangniyom, P, et al. (2017). Halal Tourism Strategy to Promote Sustainable Cultural Tourism in Thailand, 2017. CEBU International Conference on Studies in Arts, Social Sciences and Humanities (SASSH-17) Jan. 26-27, Cebu (Philippines).

Ramli, N., \& Zawawi, M. (2017). Sharia Compliant Hospitality Services or Muslim Friendly Hospitality Services: Searching for a Balance. Proceedings Books: 1311.

Riaz, M.N. and Chaudry, M.M. (2004). Halal Food Production, CRC Press, Boca Raton, FL.

Riyanto, S. (2012). Prospek Bisnis Pariwisata Syariah. Jakarta: Republika. 
Saidi, S. and Hammami, S. (2011). The Role of Transport and Logistics to Attract Foreign Direct Investment in The Developing Countries, Logistics (LOGISTIQUA), 2011. $4^{\text {th }}$ International Conference in Hammamet, Tunisia : 484-489.

Samori, Z., Md Salleh, N.Z. and Khalid, M.M. (2015). Current Trends in Halal Tourism: Cases on Selected Asian Countries. Tourism Management Perspectives Journal, Vol. 19: 131-136.

Shakona, Maloud et. al. (2014). Understanding The Traveling Behavior of Muslims in the United States. International Journal of Culture, Tourism and Hospitality Research, Vol. 9(1).

Sucipto, H. \& Andayani, F. (2014). Wisata Syariah; Karakter, Potensi, Prospek dan Tantangannya. Jakarta: Grafindo Books Media dan Wisata Syariah Consulting.

Tanjung, H., \& Devi, A. (2013). Metodologi Penelitian Ekonomi Islam. Gramata Pub.

Tresna, O. M. et. al. Halal Town as Innovation for Tourism, dalam Proceedings of 55th The IRES International Conference, Seoul, South Korea, 30th-31st December 2016, ISBN: 978-93-86291-71-4.

Wardani, M. P. \& Nasution, N.A. (2016). Kontribusi Pengembangan Pariwisata Danau Toba melalui Skema BOP (Badan Otorita Pariwisata) Bagi Masyarakat di Sekitar Danau Toba. Call for Paper FW Great Event, 2016.

West Nusa Tenggara Governor Regulation. (2015). Halal Tourism, No. 51.

Winarti, O. (2017). Halal Tourism in Indonesia: Does it Attract only Muslim Tourists?. Jurnal Studi Komunikasi, Vol. 1(3): 232-239.

Wingett, F., \& Turnbull, S. (2017). Halal Holidays: Exploring Expectations of Muslim-friendly Holidays. Journal of Islamic Marketing.

Yousaf, S., \& Xiucheng, F. (2018). Halal Culinary and Tourism Marketing Strategies on Government Websites: A Preliminary Analysis. Tourism Management, Vol. 68: 423-443. 